\title{
Effects of charcoal hearth soil on forest regeneration: Evidence from a two-year experiment on tree seedlings
}

\author{
Elisa Carrari ${ }^{\mathrm{a}, *}$, Evy Ampoorter ${ }^{\mathrm{b}}$, Filippo Bussotti ${ }^{\mathrm{c}}$, Andrea Coppi ${ }^{\mathrm{d}}$, Ana Garcia Nogales ${ }^{\mathrm{e}}$, \\ Martina Pollastrini ${ }^{\mathrm{f}}$, Kris Verheyen ${ }^{\mathrm{b}}$, Federico Selvi $^{\mathrm{c}}$ \\ ${ }^{a}$ Istituto per la Protezione Sostenibile delle Piante, National Research Council, Via Madonna del Piano 10, Sesto Fiorentino, Italy \\ ${ }^{\mathrm{b}}$ Department of Forest and Water Management, Forest \& Nature Lab (ForNaLab), Gent University, Geraardsbergsesteenweg 267, B-9090 Gontrode, Belgium \\ ${ }^{c}$ Department of AgriFood Production and Environmental Sciences, Section of Soil and Plant Sciences, Laboratories of Botany, University of Firenze, P.le Cascine 28, 50144 \\ Firenze, Italy \\ d Department of Biology, Botanical Laboratories, University of Firenze, Via G. La, Pira 4, 50121 Firenze, Italy \\ e Department of Physical, Chemical and Natural Systems, Pablo Olavide University, Carretera de Utrera Km 1, 41013 Seville, Spain \\ ${ }^{\mathrm{f}}$ Council for Agricultural Research and Economics, Research Centre for Forestry and Wood, Viale Santa Margherita 80, 52100 Arezzo, Italy
}

\section{A R T I C L E I N F O}

\section{Keywords:}

Charcoal enriched soil

Kiln sites

Photosynthetic efficiency

Seed germination

Soil properties

Tree regeneration

\begin{abstract}
A B S T R A C T
Production of wood charcoal is a traditional form of forest use that lasted for millennia in most temperate regions, vanishing only some decades ago in the Mediterranean countries. Here, the abandoned charcoal hearths form a network of microhabitats with peculiar vegetation and soil conditions. Previous observational studies showed that establishment of woody species at these sites is severely hindered for unknown reasons. To test the effects of charcoal hearth soil on tree growth we used a common garden experiment with three major EuroMediterranean forest trees with different traits and ecology, one evergreen (Quercus ilex, holm oak) and two deciduous (Fagus sylvatica, beech, and Quercus cerris, Turkey oak). These were sown on control and charcoalenriched soil collected in forest hearths abandoned since decades. Seed germination, seedling growth, photosynthetic efficiency and mortality were measured over a period of two years. Some responses were speciesspecific, while others were possibly associated to key traits such as evergreen vs. deciduous habit. Although charcoal soil effects were mainly positive on growth rate (height increase), they were mostly negative on germination of beech seeds, survival of holm oak seedlings, and photosynthetic efficiency. Although total biomass was not significantly affected, the root:shoot ratio was increased as a possible effect of physiological drought on hearth soil. These results support field-based evidence that the long persistence of charcoal remains in the soil may be not a favourable condition for forest regeneration. Management implications concern the use of biochar practices to promote forest restoration, which should be further tested on a wide range of species in different lifestages before applications in the field, also considering its long-term consequences.
\end{abstract}

\section{Introduction}

Traditional forms of land use have shaped ecosystems since the times of the first civilizations and still affect present-day soil properties also in forest habitats (Glatzel, 1991; Verheyen et al., 1999; Dupouey et al., 2002; Baeten et al., 2010). Via their influence on soil characteristics, past land uses have also deeply affected plant diversity, composition and structure of woodlands, especially in the Mediterranean region (Arianoutsou, 2001; Lloret and Vilà, 2003; Blondel, 2006; Bartha et al., 2008; Kopecký et al., 2013; Nocentini and Coll, 2013). The production of wood charcoal is among the oldest forms of human use in these forests. This existed since the Neolithic and continued for millennia in different continents (Montanari et al., 2000; Ludemann, 2003, Ludemann, 2010; Deforce et al., 2013) to be almost completely abandoned in the 19th century due to the rapidly increasing use of coal (Deforce et al., 2013). As a legacy of this widespread practice, a very high number of spots of charcoal-enriched soil remains nowadays in most European forests (Ludemann, 2011), especially in the Mediterranean countries where the activity lasted until a few decades ago (Blondel, 2006; Nocentini and Coll, 2013; Carrari et al., 2017, Mastrolonardo et al., 2018). Such spots, the so-called "charcoal hearth sites" (or charcoal kilns and charcoal kiln sites), still appear today as

Abbreviations: SR14, survival rate at the first year (2014); SR15, survival rate at the second year (2015); Fv/Fm, maximum quantum yield for primary photochemistry of dark-adapted

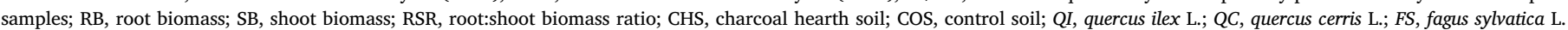

* Corresponding author.

E-mail address: elisa.carrari@ipsp.cnr.it (E. Carrari). 
small, ovoid terraces (30-45 $\left.\mathrm{m}^{2}\right)$ with flat surface and black-colored soil (Ludemann, 2003; Hardy et al., 2016; Kerré et al., 2016; Raab et al., 2017).

Previous studies in broadleaf woodlands showed that these sites have long-lasting legacy effects on soil properties and vegetation characteristics (Mikan and Abrams, 1995, 1996; Young et al., 1996; Wittig et al., 1999; Borchard et al., 2014; Raab et al., 2015; Hardy et al., 2016). Regardless of the abandonment time the soil is usually characterized by a distinct "charcoal layer" $10-80 \mathrm{~cm}$ deep (Mastrolonardo et al., 2018). In this layer, charcoal fragments in German sites were on average 2.6 times thicker than in the adjacent forest (Raab et al., 2017). In most studies, soil properties resulted deeply altered mainly due to the high content of both black and organic carbon (Borchard et al., 2014; Hardy et al., 2016). Despite a higher C:N ratio, the total N was also usually increased (e.g. Carrari et al., 2016a; Criscuoli et al., 2014). Moreover, cation exchange capacity per unit of organic carbon was higher than in the natural forest soil, even in sites older than 150 years (Hardy et al., 2016). Soil reaction was found to depend on the time since abandonment, with higher $\mathrm{pH}$ values in sites $<150$ years old (e.g. Mikan and Abrams, 1996; Criscuoli et al., 2014) and lower values where the activity ceased at least 150 years ago, as in the Wallonian area (Hardy et al., 2016).

How changes in soil conditions influence forest vegetation in terms of composition, diversity and productivity is still not well understood. Regeneration of woody species on old charcoal sites was recently found to be affected in different forest types of the Mediterranean region (Carrari et al., 2016a,b), while contrasting results were found in Germany (Krause and Möseler, 1993; Wittig et al., 1999; Borchard et al., 2014) and North America (Mikan and Abrams, 1995; Young et al., 1996; Hart et al., 2008), possibly due to different soil types (Borchard et al., 2014). In the Mediterranean, positive or neutral effects were observed on the species richness and composition of young seedlings in the understorey (plant height $<1.30 \mathrm{~m}$ ), depending on the forest type, while a strong decline of older individuals in the "established regeneration" layer (tree height of 1.3-4 m) was evident in all forest types (Carrari et al., 2016b). A similar detrimental influence on woody species was found in the old platforms of mixed oak-beech forests in eastern North America (Mikan and Abrams, 1995; Young et al., 1996). Overall, it appeared that the local conditions of charcoal sites severely hinder the recolonization processes that usually occur in forest gaps caused by natural events or other forms of human disturbance. However, the observational nature of these previous investigations did not allow to understand whether the causes for this blocked forest dynamics are connected to the soil conditions or other factors. At present, the only experiments about plant growth on soils enriched with charred wood remains were focused on the effects of biochar practices. Despite a large variability of responses, biochar is globally known to have mainly positive effects on plant growth due to improved chemical and physical characteristics of the soil (Baronti et al., 2010; Sohi et al., 2010; Vaccari et al., 2011). In agricultural systems, biochar treatments were found to increase water availability and ameliorate structure and formation of soil aggregates (Lehmann and Joseph, 2009) enhancing nitrogen availability (Rondon et al., 2007; DeLuca, 2009; Nelissen et al., 2012, 2015) and slowing down the release of nutrients (Yanai et al., 2007, Kammann et al., 2015), due to the organic coating formation (Hagemman et al., 2017).
Largely positive effects were also observed in forest biochar experiments, in which woody plants responded with a mean biomass increase of $41 \%$ (Thomas and Gale, 2015). However, these are in contrast with the mostly negative effect of charcoal sites on the establishment and growth of trees observed in the field in Italy (Carrari et al., 2016a,b) and North America (Mikan and Abrams, 1995, 1996). Such discrepancy may also point to factors associated with other properties of the charcoal hearth soil, rather than the accumulation of pyrogenic charcoal per se. These include the cascading effects of repeated slash pile and wood burning on the soil structure and chemical properties (Oswald et al., 1998) with consequent negative impact on the arbuscular mycorrhizal fungi (Korb et al., 2004) and microbial communities (Jiménez Esquilín et al., 2007), or the presence of potentially harmful soluble salts that may cause physiological drought (Mikan and Abrams, 1995). In addition, other "external" factors may contribute to the difficult establishment of woody species on charcoal platforms, such as heavy ungulate pressure that use these as preferential resting and grazing sites, or human disturbance as they are often located along old forest tracks (Carrari et al., 2017).

To understand the effect of hearth soil on the early stages of tree growth separately from those of the potential confounding factors above, we performed an ex-situ common garden experiment based on the two-years cultivation of three major forest species on hearth and control soil from their respective forest sites. Hence, this work aims at better understanding whether the hearth soil by itself acts as stress factor for tree regeneration at the early stages of growth, which is relevant before investigating the specific chemical, physical or biological properties of this substrate that cause the observed effects. Specifically, we examined the effect on the following processes: i) seed germination, ii) seedling mortality, iii) growth of seedlings in terms of height and above and below-ground biomass, and iv) photosynthetic efficiency of the seedlings.

\section{Material and methods}

\subsection{Study species}

We selected the most representative tree species of the three main forest types historically used in Tuscany for charcoal production: (1) the holm oak (Quercus ilex L. - QI) for evergreen sclerophyll forests of the Mediterranean coastal belt, (2) the Turkey oak (Quercus cerris L. - QC) for thermophilous deciduous forests of the internal hill belt, and (3) the beech (Fagus sylvatica L. - FS) for the montane belt forests. The sampling sites were located in the northern Apennines and in the area of Colline Metallifere in central Tuscany; main geographical and environmental features of the sites are given in Table 1 . For each species, around 1000 healthy seeds were collected in autumn 2013 under two mother trees growing in close proximity of a charcoal hearth in the respective forest type.

\subsection{Common garden set-up}

In the same spot of seed collection, a representative and well preserved charcoal hearth platform repeatedly used until 50-60 years ago for wood charcoal production (supposedly at time intervals of 10-20 years) was selected in each forest type for collection of soil

Table 1

Main geographical and environmental variables of the sampling sites in Tuscany; Quercus ilex (QI), Quercus cerris (QC), Fagus sylvatica (FS).

\begin{tabular}{|c|c|c|c|c|c|c|c|c|}
\hline & Geographic area & Locality & Forest type & Lat & Long & $\begin{array}{l}\text { Altitude } \\
\text { m a.s.L. }\end{array}$ & Parent rock material & Soil type \\
\hline$Q I$ & Colline Metallifere & Val di Farma & evergreen sclerophyll & $43^{\circ} 4^{\prime} 21.54^{\prime \prime} \mathrm{N}$ & $11^{\circ} 16^{\prime} 43.20^{\prime \prime} \mathrm{E}$ & 508 & Quarzitic sandstone & Cambisol \\
\hline$Q C$ & Colline Metallifere & Val di Farma & thermophilous deciduous & $43^{\circ} 4^{\prime} 21.60^{\prime \prime} \mathrm{N}$ & $11^{\circ} 16^{\prime} 17.64^{\prime \prime} \mathrm{E}$ & 484 & Quarzitic sandstone & Cambisol \\
\hline FS & $\mathrm{N}$ Apennines & Colla di Casaglia & beech forests & $44^{\circ} 3^{\prime} 5.46^{\prime \prime} \mathrm{N}$ & $11^{\circ} 26^{\prime} 18.54^{\prime \prime} \mathrm{E}$ & 989 & Siltitic sandstone & Cambisol \\
\hline
\end{tabular}


material and samples for chemical analysis. No living woody plants were present above $1.3 \mathrm{~m}$ in these three platforms at the moment of soil collection. After removal of the litter layer, five soil cores were collected at ca. $15 \mathrm{~cm}$ of depth, including the whole organic layer, from five points of the hearth surface and of the control spot. Next, the blackish charcoal-enriched soil (anthrosol-like, hereafter indicated as "CHS") was collected at a depth of ca. $15 \mathrm{~cm}$ from the whole platform surface (ca. $32-42 \mathrm{~m}^{2}$ ). The control soil ("COS") was collected from the forest floor with the same procedure of CHS in a single spot adjacent to the hearth platform, excluding downhill locations to avoid potential charcoal "contamination" by runoff. The five soil samples from each site were dried, sieved using a $2 \mathrm{~mm}$ mesh size and analysed for total C, total N, S (Elementar analyser, type Vario Macro Cube in configuration CNS, with Argon as carrier gas) and $\mathrm{pH}\left(\mathrm{H}_{2} \mathrm{O}\right)$.

The common garden was established in November 2013, in a green open space near the town of Florence (Italy; $43.795135 \mathrm{~N} ; 11.177350$ E), at $40 \mathrm{~m}$ a.s.L. The climate is humid temperate, with $14.6^{\circ} \mathrm{C}$ of mean annual temperature and $872.6 \mathrm{~mm}$ of rainfall (Lamma Toscana, http:// www.lamma.rete.toscana.it). Variations of monthly rainfall and temperature for the study site during the experiment period (October 2013August 2015) are shown in Fig. 1.

We filled 450 3L plastic pots $(15 \times 15 \times 20 \mathrm{~cm})$ with the two types of soil materials ( 75 CHS and 75 COS for each species). The pots were placed in three adjacent blocks (one per species), mixing the CHS and $\operatorname{COS}$ at random within each block. Partial shading to the pots was provided by cultivated ash trees (Fraxinus angustifolia Vahl), to simulate the natural canopy shading at the forest floor. A thick plastic sheet was placed under the pots in order not to allow roots going out from the pots and penetrating into the local soil. For each species, 450 apparently healthy seeds were randomly selected and sown, placing three of them per pot in a regular triangle-like design to maximize their distance (225 seeds per species). The seeds of the beech, which are characterized by an intermediate physiological dormancy (Baskin and Baskin, 2006), were sown on 25 October 2013, after 20 days of stratification at $4 C^{\circ}$, while the two oak species were sown without chilling ( $Q C$ on November 14, 2013 and QI on November 21, 2013). The pots received only ambient rainfall during the experiment period, except for two "emergency" waterings carried out July 4, 2014, and July 15, 2015, when each plot received $1 \mathrm{~L}$ of water to help seedlings overcome periods of high temperatures and drought.

\subsection{Seed germination and seedling mortality}

The germination rate of the three species was determined as mean of the percentages of seedlings emerged from the soil at the end of June 2014, per single pot (e.g. one seed/pot $=33 \%$; two seeds/pot $=66 \%$; three seeds $/$ pot $=100 \%$ ). Then, we made two mortality counts during the experiment, one at the end of the first growing season (1 November 2014) and one at the end of the whole experiment (1 August 2015). Throughout the experiment period, we made a visual evaluation once per month and the very few seedlings that died due to biotic causes such as pests and pathogens were not considered. Survival rate was estimated as the difference in the percentage of seedlings survived per pot between June 2014 and November 2014 (hereafter indicated as SR14) and between November 2014 and July 2015 (hereafter indicated as SR15).

\subsection{Seedling height and biomass}

Seedling height $(\mathrm{H})$ was measured at monthly intervals with a stop during winter 2013-2014, e.g. after germination. A total of 10 measurements were taken, eight in 2014 (April- November 2014) and two in 2015 (May and June 2015).

At the end of the experiment (1 August 2015), 35 seedlings were randomly selected for each species to determine the dry weight of the above-ground (shoot biomass, SB) and below-ground parts (root biomass, RB) as well as their ratio (RSR). In order to separate SB from RB, plants were cut at the root collar (e.g. above the insertion point of the first root). Roots were first carefully cleaned by hand and then washed with water under pressure to remove the soil particles on their external surface. Above and below ground dry biomass values were determined after drying the samples in an oven at $70^{\circ} \mathrm{C}$ for $48 \mathrm{~h}$ until they reached a constant weight.

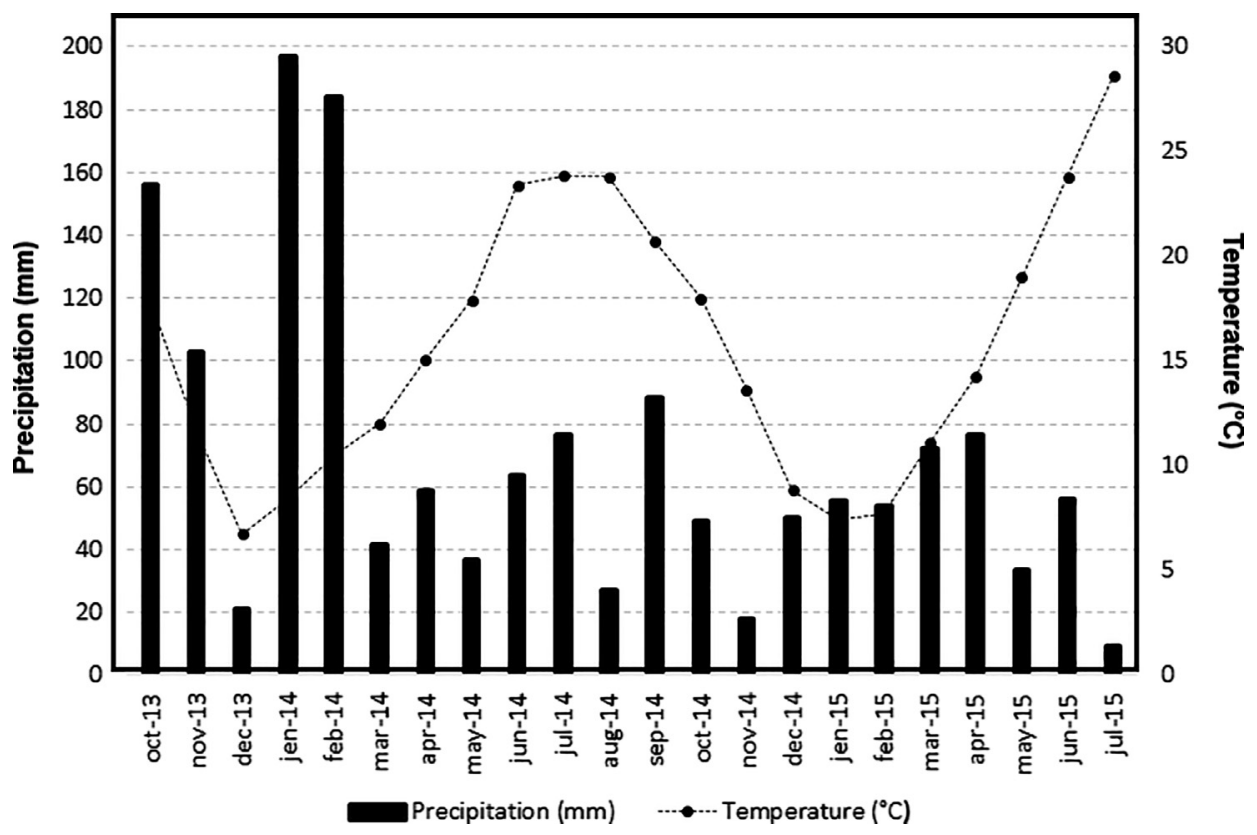

Fig. 1. Rainfall and temperature during the experiment. Total monthly rainfall (precipitation-mm) and temperature $\left({ }^{\circ} \mathrm{C}\right.$ ) for the study site from October 2013 to August 2015.

Source: Lamma Toscana, http://www.lamma.rete.toscana.it. 


\subsection{Chlorophyll a fluorescence analysis}

At monthly intervals, Chlorophyll $a$ fluorescence (ChlF) emission transients were measured 10 times for the two deciduous trees ( $Q C$ and FS, May-November 2014 and May-July 2015). For the evergreen holm oak (QI) the ChlF was also monitored three times during the winter season (December, January and March).

Measurements of ChlF were taken on a random sample of 20 seedlings per species on the two types of soil material, using a direct HandyPEA fluorimeter (Plant Efficiency Analyzer, Hansatech Instruments Ltd., Petney, Norfolk, UK) on two (before June 2014) or three leaves, after $30 \mathrm{~min}$ of sample dark-adaptation with leaf-clips. The measure was repeated each one day per month, from 10:00 to 13:00. Leaves for measurements were changed only when apparently damaged or injured for various reasons.

The status of the photosynthetic apparatus was analysed by means of the maximum quantum yield for primary photochemistry of the darkadapted samples i.e., the fraction of the total energy flux trapped by the photosystem II (PSII) reaction centres, by applying the well-known equation [Fm-Fo] $/ \mathrm{Fm}=\mathrm{Fv} / \mathrm{Fm}$ (Paillotin, 1976). The quantum yield of primary photochemistry is a function of the photochemical $(\mathrm{kP})$ and non-photochemical $(\mathrm{kN})$ de-excitation constants $[\mathrm{Fv} / \mathrm{Fm}=\mathrm{kP} /$ $(/ \mathrm{kP}+\mathrm{kN})]$ and represents the "steady" structure of PSII (Strasser et al., 2000, 2004). The reduction of the parameter Fv/Fm is widely recognized as indicator of several stress factors, such as mineral nutrient deficiency, air and soil pollution, excess of light and drought (Baker and Rosenqvist, 2004; Kalaji et al., 2014, 2017).

\subsection{Data analyses}

All analyses were performed in R.5.0 (R core team, 2015). Statistical analysis for detecting substrate effect (CHS/COS) were conducted separately for the three species.

Normal distribution and homogeneity of variance for all the soil variables as well germination rate, SR14, SR15, H, Fv/Fm, RB, SB and RSR were tested using the Lilliefors test and Bartlett's test, respectively (Gross, 2015).

Soil variables and values of seed germination rate, SR14, SR15, RB, SB and RSR of seedlings were compared between the two types of soil material ("soil factor") using the T test or the Mann-Whitney-Wilcoxon Test, depending on normality of row data. For $\mathrm{H}$ and Fv/Fm, which were measured monthly on the same plants, the soil effect was tested with a repeated measurement approach by using the function aov in $\mathrm{R}$ $[y \sim$ soil * time + Error (id.plant/soil factor * time), data $]$.

\section{Results}

\subsection{Soil properties}

The topsoil of the three sampled charcoal hearths was characterized by a single and continuous layer of black color, rich in wood charcoal fragments of variable size. As expected, CHS was always considerably enriched with total $\mathrm{C}$ compared with the respective control (on average over three time higher; Table 2). The $\mathrm{C} / \mathrm{N}$ ratio was also consequently higher in CHS of the QC and FS sites, despite the parallel increase of total Nitrogen. This was less marked and significant only for the $Q C$ sites. Sulphur data did not show a consistent pattern of variation and differed significantly only in the case of QI, where it was higher in COS. Values of $\mathrm{pH}$ tended to be higher in CHS, but not significantly.

\subsection{Seed germination and seedling mortality}

The germination and survival rates of the three species showed different responses to the "soil factor" (Fig. 2). A negative effect of CHS on germination rate was found for FS: here, the emerged seedlings were 127 vs. 165 on COS, corresponding to $65.1 \pm 26 \%$ of germinated seeds per pot on CHS vs. $76.4 \pm 28.2 \%$ on $\operatorname{COS}(\mathrm{p}=0.018$ ). The survival rate was not influenced by the soil in the first year, however, on the second year of the experiment the evergreen oak $Q I$ showed a significantly higher SR on COS: $+5 \%$ per pot of SR 15 . The deciduous oak $Q C$ did not show significant variations in germination and survival rates, despite a lower percentage of germinated seeds on CHS $(-3 \%)$ as in the case of the beech. The Turkey oak showed also an opposite trend compared to the other two species, with a higher mortality in the first year on both soils, compared to second year.

No significant effects occurred on the mortality rate of FS, though the percentage of seedlings that survived was higher on COS (ca. $2 \%$ per pot).

\subsection{Seedling height and biomass}

Significant differences in response to the "soil factor" were found in terms of height growth of $Q I$ and $Q C$. Independently from the "time" factor, seedlings of the two oak species were always taller on CHS ( $\mathrm{p}=0.011$ and $\mathrm{p}=0.031$ respectively), than those growing on COS (Fig. 3). Such difference started on May 2014 and was maintained until the end of the experiment. For the QI seedlings, the largest difference was reached in July 2014, when the height of those on CHS was increased by $34 \%$ compared with those on COS; such difference was reduced to $5 \%$ in the second year. Also for $Q C$ the largest difference was reached during the summer months of the first year, when the seedlings on CHS were on average $18 \%$ taller. Beech seedlings were also generally smaller on COS, but not significantly (Fig. 3).

Few significant differences were found in terms of root (RB) and stem biomass (SB). The total biomass of single plants was widely variable, with dry weight values ranging from $0.02 \mathrm{~g}$ to $6.12 \mathrm{~g}$ on CHS and from $0.13 \mathrm{~g}$ to $5.75 \mathrm{~g}$ on COS. The largest difference between the two treatments was found in FS, where RB and SB produced on CHS were $32 \%$ and $28 \%$ higher than on control, respectively (Table 3 ); in the latter case $(\mathrm{RB})$ such difference was significant $(\mathrm{p}=0.05)$. A similar response was shown by $Q C$, albeit without significant differences, where the root biomass on CHS was $15 \%$ higher than on COS. Since the above-ground biomass was more abundant on COS, however, the difference in total biomass was only very minor. The evergreen oak QI showed almost no differences in terms of root biomass, while the aboveground biomass was ca. $12 \%$ higher on COS; in spite of this, no difference in RSR was detected (Table 3).

Table 2

Total Nitrogen (N\%), Carbon (C\%), C/N ratio, Sulphur (S\%) and pH of the charcoal hearth (CHS) and control soil (COS) used for the common garden experiment for each of the three species Q. ilex (QI), Q. cerris $(Q C)$ and F. sylvatica (FS). The soil effect is expressed as result of T test following checking of normality.

\begin{tabular}{|c|c|c|c|c|c|c|c|c|c|c|c|c|c|c|c|}
\hline & $\mathrm{N} \%$ & & & $\mathrm{C} \%$ & & & $\mathrm{C} / \mathrm{N}$ & & & $\mathrm{S} \%$ & & & $\mathrm{pH}$ & & \\
\hline & CHS & $\cos$ & p-value & CHS & $\cos$ & $\mathrm{p}$-value & CHS & $\cos$ & $\mathrm{p}$-value & CHS & $\cos$ & $\mathrm{p}$-value & CHS & $\cos$ & $\mathrm{p}$-value \\
\hline$Q I$ & 0.332 & 0.203 & n.s. & 9.545 & 3.044 & $<0.001$ & 28.750 & 14.995 & n.s. & 0.015 & 0.030 & 0.050 & 5.756 & 5.199 & n.s. \\
\hline$Q C$ & 0.593 & 0.338 & 0.005 & 16.318 & 4.746 & $<0.001$ & 27.518 & 14.041 & $<0.001$ & 0.046 & 0.036 & n.s. & 5.488 & 4.835 & n.s. \\
\hline FS & 0.461 & 0.307 & n.s. & 7.343 & 3.248 & 0.035 & 15.928 & 10.580 & $<0.001$ & 0.024 & 0.035 & n.s. & 5.565 & 4.929 & n.s. \\
\hline
\end{tabular}




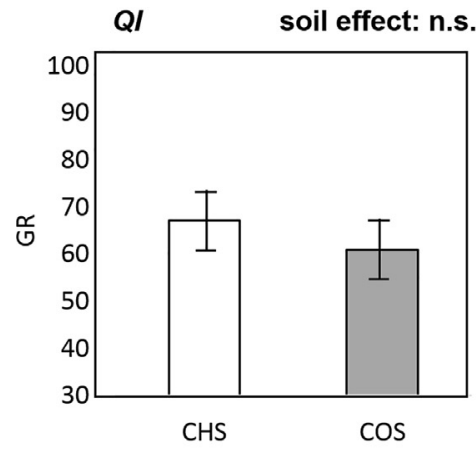

QC

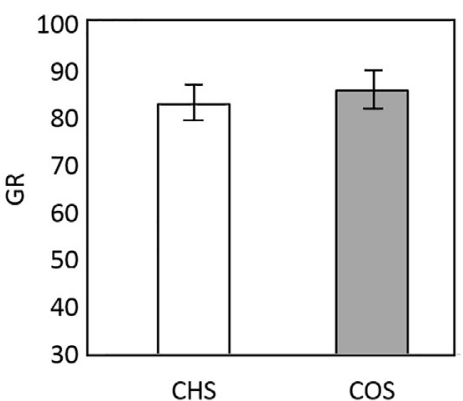

FS

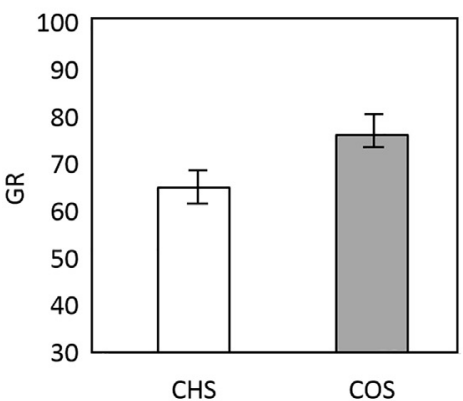

QI

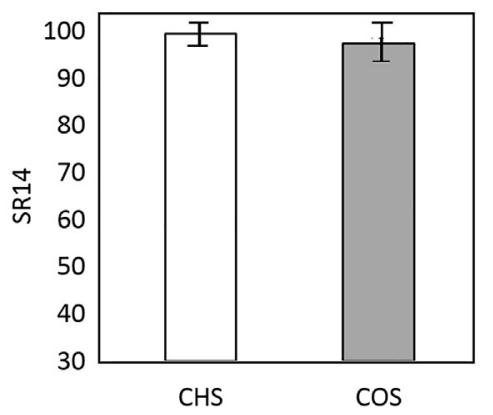

QC

soil effect: n.s.

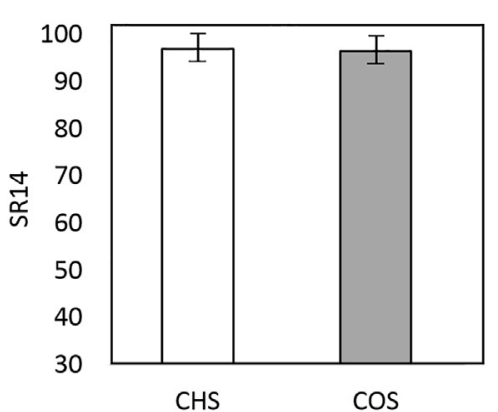

FS

soil effect: $n . s$.

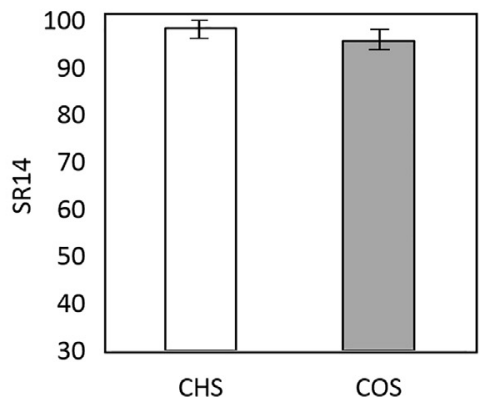

QI soil effect: $p=0.01$

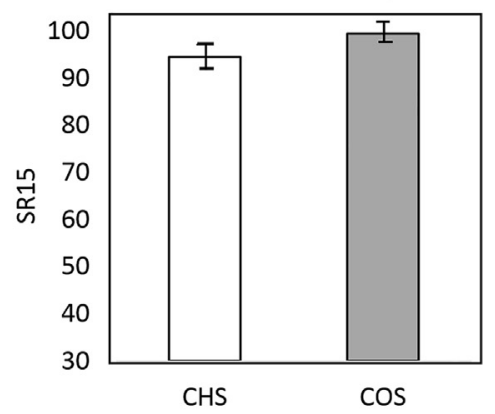

QC soil effect: $n . s$.

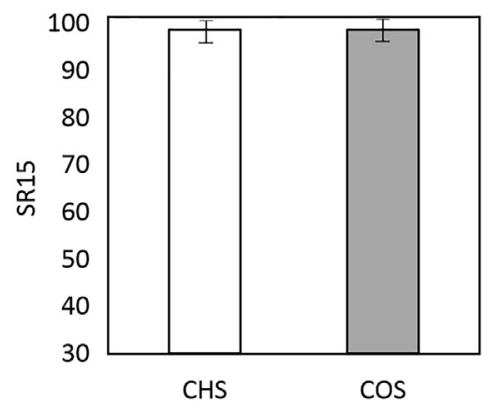

FS

soil effect: n.s.

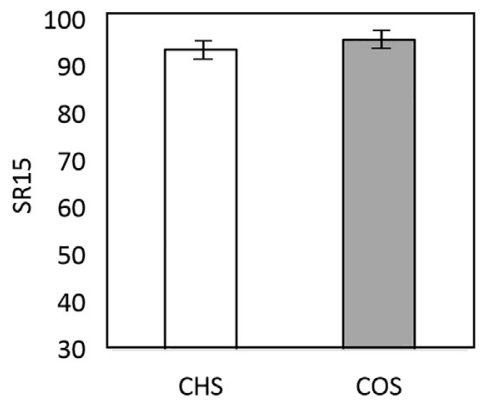

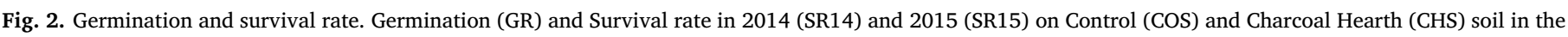

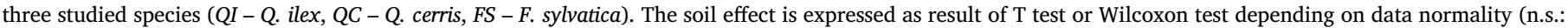
$\mathrm{p}>0.05$ ). Error bars represent the standard error of the mean.
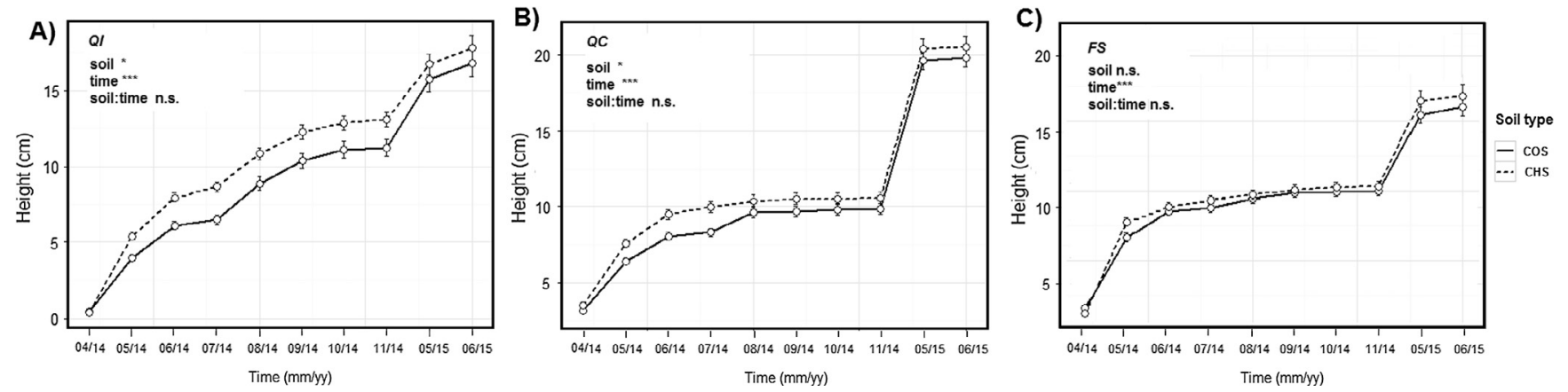

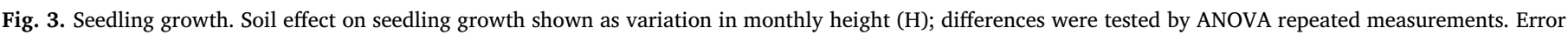
bars represent the standard error of the mean for each measure.

\subsection{Photochemical efficiency (Fv/Fm)}

The parameter Fv/Fm showed significant differences in the two oak species depending on the "soil factor": in $Q I$ and $Q C$ the interaction between soil and time was highly significant $(\mathrm{p}=0.004$ and $\mathrm{p}<0.001$, respectively). In the evergreen oak $Q I$, the maximum quantum yield was constantly higher for seedlings grown on CHS during the whole first year, while the second year this species underwent strong oscillations (Fig. 4A). The deciduous oak $Q C$ showed higher values of Fv/Fm on CHS, than on COS, until July of the first year, with a maximum difference of 1.5\% (May 2014; Fig. 4B). However, a sharp reversal occurred in summer months (from July) and Fv/Fm decreased 
Table 3

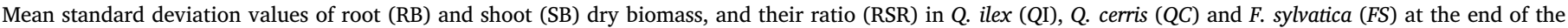
experiment. The soil effect is expressed as result of $\mathrm{T}$ test or Wilcoxon test depending on data normality (ns: $\mathrm{p}>0.05$ ).

\begin{tabular}{|c|c|c|c|c|c|c|c|c|c|}
\hline & \multicolumn{3}{|l|}{$\mathrm{RB}$} & \multicolumn{3}{|l|}{ SB } & \multicolumn{3}{|l|}{ RSR } \\
\hline & CHS & $\cos$ & p-value & CHS & $\cos$ & p-value & CHS & $\cos$ & $\mathrm{p}$-value \\
\hline$Q I$ & $0.756 \pm 0.346$ & $0.769 \pm 0.474$ & ns & $1.432 \pm 0.585$ & $1.610 \pm 0.986$ & ns & $0.520 \pm 0.187$ & $0.483 \pm 0.181$ & ns \\
\hline$Q C$ & $1.201 \pm 0.890$ & $1.042 \pm 0.51$ & ns & $1.028 \pm 0.669$ & $1.058 \pm 0.580$ & ns & $1.161 \pm 0.409$ & $1.035 \pm 0.335$ & ns \\
\hline$F S$ & $0.565 \pm 0.329$ & $0.428 \pm 0.244$ & 0.05 & $0.721 \pm 0.443$ & $0.563 \pm 0.320$ & ns & $0.913 \pm 0.447$ & $0.801 \pm 0.351$ & ns \\
\hline
\end{tabular}
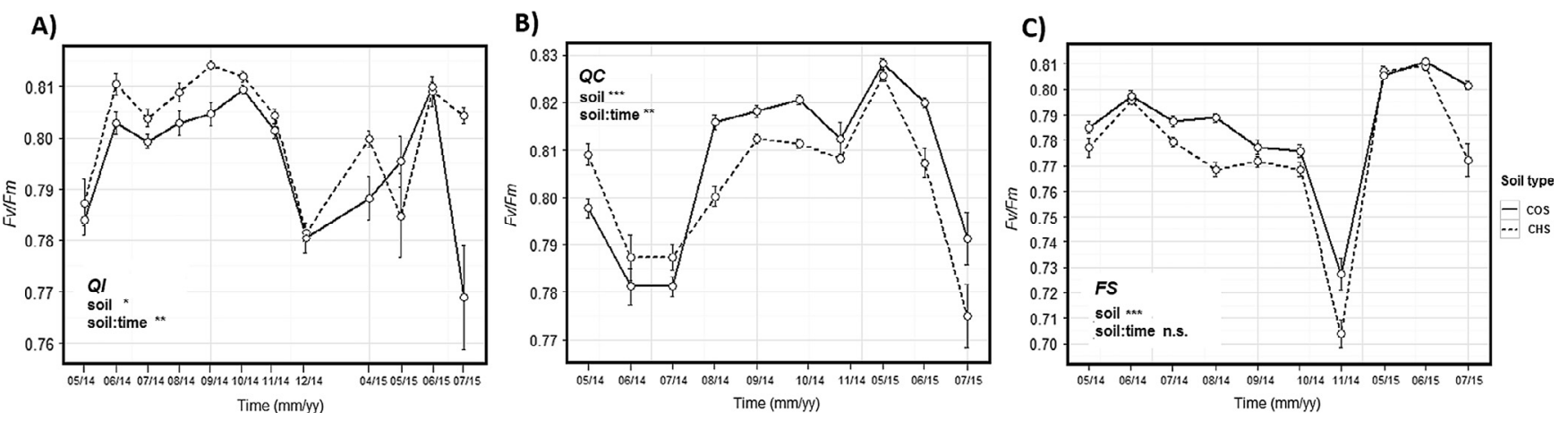

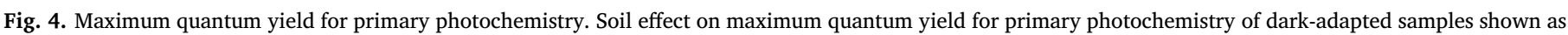

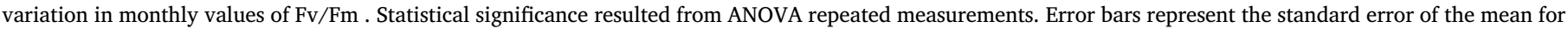
each measure.

up to $1.8 \%$ on hearth soil. This difference was maintained until the winter, then it increased again at the end of the experiment up to $2 \%$. The Fv/Fm index for FS was consistently higher on COS during the whole experiment; Anova test indeed revealed a significant effect of the "soil factor" without considering the interaction with "time" (p < 0.001; Fig. 4C).

\section{Discussion}

The present study is the first one experimentally investigating the responses of three major European forest tree species to the treatment with charcoal-enriched soil from hearth sites repeatedly used until 50-60 years ago for the production of wood charcoal in deciduous and evergreen broadleaf forests. Although using different CHS-COS soil material from the native sites of each species did not allow to make direct comparisons between the species responses, this was adopted to replicate as much as possible the field conditions of the three species. Only by this approach it was possible to better understand the effects of the substrate as it is in each site, except for its original structure that was unavoidably lost during collection for this experiment.

\subsection{Seed germination and seedling mortality}

Overall, effects of soil on the initial life stages were divergent and depended on both the functional group (evergreen vs. deciduous habit), and, to a lesser extent, species identity. Age of the seedlings was also relevant, as the direction of some of the responses changed from the first to the second year of the experiment. Species-specific responses were observed for seed germination and seedling survival. While the deciduous oak $Q C$ was not significantly affected, neither for germination nor for survival, the evergreen holm oak was apparently favoured on CHS in the first year of the experiment, with a higher germination rate coupled with lower mortality than on COS. This result is consistent with the lack of a negative effect of CHS on the density of young ( $\leq 1 \mathrm{yr}$. old) QI seedlings recently observed in sclerophyllous Italian forests (Carrari et al., 2016b). Similarly, a recent experimental study (Reyes et al., 2015) highlighted the insensitivity of this species to soils added with ash and black carbon, such as those affected by wildfires.
However, this initial positive effect on germination was largely cancelled by the increased mortality observed during the second year, showing the substantially negative effect of CHS on the establishment of seedlings. This was even more evident for the beech, which germinated significantly better on COS (plus 17\%). Given the lack of significant differences in the survival rate of this species on the two types of soil material, decreased rate of seed germination may be one of the causes for the lower density of seedlings observed on CHS in the field (Carrari et al., 2016b).

The overall effect of CHS on seed germination and seedling survival was therefore life-stage dependent and not generalizable but, in our experiment, only negative when present.

\subsection{Seedling height and biomass}

By contrast, CHS had a mostly positive effect on growth rate. Seedlings grown on COS were taller in the two species of Quercus and to, a lesser extent, in the beech, suggesting that phylogenetic affinity may affect this response more than functional traits such as evergreen (Q. ilex) vs. deciduous ( $Q$. cerris). These results are apparently in line with a broad range of studies reporting enhanced plant growth in biochar experiments on crops (Baronti et al., 2010; Sohi et al., 2010; Vaccari et al., 2011). Improved nutrient availability was likely a major cause for a positive effect on crop yield in these experiments, where especially Nitrogen has been suggested to play a key role (DeLuca, 2009; Nelissen et al., 2012). Total N in our CHS samples was tendentially higher than in $\mathrm{COS}$ and $\mathrm{pH}$ values did not indicate low $\mathrm{N}$ availability associated with acidification, despite the high C:N ratio. In hearth sites, in fact, the latter results from the abundant fraction of nonorganic C derived from charcoal, which is mostly biologically inert due to its refractory structure and poor accessibility when physically enveloped by soil particles (Brodowski et al., 2006). However, the role of $\mathrm{N}$ in promoting seedlings growth in our experiment cannot be assessed as the actual bioavailability of this nutrient was not determined. Moreover, no evidence for enhanced productivity on CHS was found in terms of biomass. Various reasons may account for this apparent discrepancy, such as different resource allocation, e.g. stem height growth but lower production of leaf biomass, or even lower tissue density on 
CHS. Similarly, different partitioning of dry matter between organs may explain the consistently higher root:shoot biomass ratio in seedlings grown on CHS, which indicates a preferential investment in the root system than in the above-ground parts. Similar evidence emerged from an experiment on north American oak species, where the increase in root:shoot ratio was related to drought stress on charcoal soil (Mikan and Abrams, 1996). The drought stress hypothesis seems plausible as it often causes an increment of the root:shoot ratio (Aroca and LuizRozano, 2012) and a stronger decrease of shoot growth vs. root growth in seedlings of woody plants subject to water limitation (Silva et al., 2012). Although pyrogenic charcoal seems to positively affect soil water holding capacity due to its porosity (Yu et al., 2013), the actual availability of charcoal-adsorbed water to plants still needs to be assessed (Karhu et al., 2011). Hence, whether the CHS can cause drought stress to plants, remains to be investigated. In addition, the higher content of exchangeable $\mathrm{Ca}, \mathrm{Mg}$ and $\mathrm{K}$ of charcoal hearth soil can lead to lower osmotic potentials of the soil solution and cause physiological drought (Mikan and Abrams, 1996), which may also contribute to explain our findings.

\subsection{Photochemical efficiency}

Chlorophyll $a$ fluorescence measurements highlighted divergent responses in the three taxa. While QI showed a greater quantum yield on CHS, QC and FS showed the opposite behaviour, suggesting that a key trait such as evergreen vs. deciduous habit is more important than phylogenetic constraints in determining the photosynthetic responses of seedlings to CHS treatment. Enhanced photosynthetic efficiency in QI seedlings on CHS underlines the high resilience and adaptive capacity of this Mediterranean tree species to a wide range of environmental conditions, including drought and nutritional stresses. By contrast, the low value of Fv/Fm (0.77) observed in the two deciduous species grown on CHS at the end of the experiment, i.e. summer 2015, is likely due to early foliar senescence with a loss functionality of the PSII reaction center. Physiological drought and reduced efficiency in the exploitation of soil nutrients are possible factors that negatively affected the photosynthetic efficiency of $F S$ and $Q C$, because of their lower resistance to water and nutritional stress in respect to QI. Young et al. (1996) observed a decrease in $\mathrm{P}$ availability in hearth soil from the Appalachian mountains, while Hardy et al. (2016) found that the topsoil of Wallonian sites was greatly depleted probably due to a lowering of $\mathrm{P}$ availability with time. Moreover, Mikan (1993) found lower P concentrations in tissue of Vaccinium corymbosum L. from hearths in Pennsylvania. Since P is an essential nutrient in photosynthetic carbon assimilation (Hidaka and Kitayama, 2013), more studies are needed on the actual availability of this element in CHS, as well as on the possible effect of its shortage on the photosynthetic efficiency of our model tree species.

\subsection{Forest management implications}

Our findings suggest that the soil of charcoal hearths abandoned since some decades is not fully favourable to the establishment of trees, despite some apparently favourable characteristics such as reduced acidity and enrichment of total Carbon (Criscuoli et al., 2014; Mastrolonardo et al., 2018). Hence, we provide no clear support to the mostly positive influence of biochar treatments on tree growth, which has recently led to suggest this practice to promote forest restoration (Thomas and Gale, 2015). In particular, using the three species of our experiment for forest restoration initiatives on charcoal amended soils cannot be recommended in the long term. One of the possible causes for this discrepant evidence may be the different time of persistence of charcoal in the soils where plants were grown and their responses were observed. In fact, most forest biochar experiments were performed on recently amended soils with seedlings $<6$ months (e.g. Chidumayo, 1994; Heiskanen et al., 2013). According to Hardy et al. (2017a,b), however, hearth soil can only be compared to soil amended with hardwood biochar more than 150 years ago, e.g. "aged" biochar. Recent findings suggest substantial differences between young and old biochartreated soils because of the negative effects linked to the ageing of biochar, such as lower nutrient availability, altered cation exchange capacity and loss of the liming effect of $\mathrm{pH}$ occurring after ca. 100 years (e.g. Hernandez-Soriano et al., 2016; Hardy et al., 2017a,b). Hence, if the application of biochar can be considered a promising strategy to offset C emissions (e.g. Lehmann et al., 2006; Kerré et al., 2016), its ageing in soil determines controversial effects on the regeneration of some forest species. Whether biochar can help forest recover in the long term depends on a better understanding of the effects of the addition of different pyrogenic charcoal types on the different life stages and physiological processes of trees, consequent to the soil structural and chemical changes caused by this practice.

\section{Conclusions}

The overall effect of charcoal hearth soil on the response variables analysed in this study was prevalently negative, matching evidence for the nearly complete lack of established regeneration of our three model species observed in the field. The high content and long persistence of charred wood is one of the primary characteristics leading to consequences similar to those of aged biochar experiments, whose effects on plant growth may not be always beneficial. On the other hand, results of this study do not allow to exclude that the observed effects are due to specific features of the hearth sites soil associated with repeated wood combustion and slash pile burning, rather than charcoal accumulation and persistence per se. This remains to be investigated. Finally, our findings suggest that responses are likely to depend on species identity and functional traits, as well as on the life-stage of the tree. Hence, selection of the more suitable tree species for afforestation on charcoal-enriched soils will also benefit from more experiments testing the responses of a wide range of taxa from the seed to the adult stage.

\section{Acknowledgements}

Authors wish to thanks Dilek Killi Haworth and Caterina Sandrini (University of Firenze) for their suggestions and help during measurements. Two anonymous reviewers provided very useful comments on the first draft of the manuscript. Research grants to FS from Ministry of University and Scientific Research and University of Florence are acknowledged. The research of KV is supported by the ERC Consolidator Grant 614839 - PASTFORWARD.

\section{References}

Arianoutsou, M., 2001. Landscape changes in Mediterranean ecosystems of Greece: implications for fire and biodiversity issues. J. Mediterr. Ecol. 165-178.

Aroca, R., Luiz-Rozano, J.M., 2012. Regulation of Root Water uptake under drought stress conditions. In: Aroca, R. (Ed.), Plant Responses to Drought Stress. Morphological and Physiological Adaptations. Springer, pp. 113-128.

Baeten, L., Hermy, M., Van Daele, S., Verheyen, K., 2010. Unexpected understorey community development after 30 years in ancient and post-agricultural forests. J. Ecol. 98, 1447-1453. http://dx.doi.org/10.1111/j.1365-2745.2010.01711.

Baker, N.R., Rosenqvist, E., 2004. Applications of chlorophyll fluorescence can improve crop production strategies: examination of future possibilities. J. Exp. Bot. 55, $1607-1621$.

Baronti, S., Alberti, G., Vedove, G.D., Gennaro, F Di, Fellet, G., Genesio, L., Miglietta, F., Peressotti, A., Vaccari, F.P., 2010. The biochar option to improve plant yields: first results from some field and pot experiments in Italy. Ital. J. Agron. 5 (1) 3-12.3-11.

Bartha, S., Merolli, A., Campetella, G., Canullo, R., 2008. Changes of vascular plant diversity along a chronosequence of beech coppice stands, central Apennines, Italy. Plant Biosyst. - Int. J. Deal. with all Asp. Plant Biol. 142, 572-583. http://dx.doi.org/ 10.1080/11263500802410926.

Baskin, C.C., Baskin, J.M., 2006. The natural history of soil seed banks of arable land. Weed Sci. 54 (3), 549-557.

Blondel, J., 2006. The "Design" of Mediterranean Landscapes: a millennial story of humans and ecological systems during the historic period. Hum. Ecol. 34, 713-729. http://dx.doi.org/10.1007/s10745-006-9030-4.

Borchard, N., Ladd, B., Eschemann, S., Hegenberg, D., Möseler, B.M., Amelung, W., 2014 Black carbon and soil properties at historical charcoal production sites in Germany. 
Geoderma 232-234, 236-242.

Brodowski, S., John, B., Flessa, H., Amelung, W., 2006. Aggregate occluded black carbon in soil. Eur. J. Soil Sci. 57, 539-546.

Carrari, E., Ampoorter, E., Bottalico, F., Chirici, G., Coppi, A., Travaglini, D., Verheyen, K., Selvi, F., 2017. The old charcoal kiln sites in Central Italian forest landscapes. Quat. Int. 1-10.

Carrari, E., Ampoorter, E., Verheyen, K., Coppi, A., Selvi, F., 2016a. Former charcoal kiln sites as microhabitats affecting understorey vegetation in Mediterranean forests. Appl. Veg. Sci. 19, 486-497.

Carrari, E., Ampoorter, E., Verheyen, K., Coppi, A., Selvi, F., 2016b. Former charcoal platforms in Mediterranean forest areas: a hostile microhabitat for the recolonization by woody species. iForest 10, 136-144. http://dx.doi.org/10.3832/ifor1701-009.

Chidumayo, E.N., 1994. Effects of wood carbonization on soil and initial development of seedlings in miombo woodland, Zambia. For. Ecol. Manage. 70, 353-357.

Criscuoli, I., Alberti, G., Baronti, S., Favilli, F., Martinez, C., Calzolari, C., Pusceddu, E., Rumpel, C., Viola, R., Miglietta, F., 2014. Carbon sequestration and fertility after centennial time scale incorporation of charcoal into soil. PLoS One 9, 1-11. http://dx. doi.org/10.1371/journal.pone.0091114.

Deforce, K., Boeren, I., Adriaenssens, S., Bastiaens, J., De Keersmaeker, L., Haneca, K., Tys, D., Vandekerkhove, K., 2013. Selective woodland exploitation for charcoal production. A detailed analysis of charcoal kiln remains (ca. 1300-1900 AD) from Zoersel (northern Belgium). J. Archaeol. Sci. 40, 681-689.

DeLuca, T., 2009. Biochar effects on soil nutrient transformations. Biochar. Environ. Manag. Sci. Technol. 251-270. http://dx.doi.org/10.4324/9781849770552.

Dupouey, J.L., Dambrine, E., Laffite, J.D., Moares, C., 2002. Irreversible impact of past land use on forest soils and biodiversity. Ecology 83, 2978-2984. http://dx.doi.org/ 10.1890/0012-9658(2002) 083[2978:IIOPLU]2.0.CO;2.

Glatzel, G., 1991. The impact of historic land use and modern forestry on nutrient relations of Central European forest ecosystems. Fertil. Res. 27, 1-8. http://dx.doi.org/ 10.1007/BF01048603.

Hardy, B., Cornelis, J.-T., Houben, D., Leifeld, J., Lambert, R., Dufey, J., 2017a. Evaluation of the long-term effect of biochar on properties of temperate agricultural soil at preindustrial charcoal kiln sites in Wallonia. Belgium. Eur. J. Soil Sci. 68, 80-89.

Hardy, B., Leifeld, J., Knicker, H., Dufey, J.E., Deforce, K., Cornélis, J.T., 2017b. Long term change in chemical properties of preindustrial charcoal particles aged in forest and agricultural temperate soil. Org. Geochem. 107, 33-45.

Hardy, B., Cornelis, J.T., Houben, D., Lambert, R., Dufey, J.E., 2016. The effect of preindustrial charcoal kilns on chemical properties of forest soil of Wallonia, Belgium. Eur. J. Soil Sci. 67, 206-216.

Hart, J.L., Van De Gevel, S.L., Mann, D.F., Clatterbuck, W.K., 2008. Legacy of charcoaling in a Western Highland Rim Forest in Tennessee. Am. Midl. Nat. 159, 238-250.

Heiskanen, J., Tammeorg, P., Dumroese, R.K., 2013. Growth of Norway spruce seedlings after transplanting into silty soil amended with biochar: a bioassay in a growth chamber-short communication. J. For. Sci. 59, 125-129.

Hernandez-Soriano, M.C., Kerré, B., Goos, P., Hardy, B., Dufey, J., Smolders, E., 2016. Long-term effect of biochar on the stabilization of recent carbon: soils with historical inputs of charcoal. Gcb Bioenergy 8 (2), 371-381.

Hidaka, A., Kitayama, K., 2013. Relationship between photosynthetic phosphorus-use efficiency and foliar phosphorus fractions in tropical tree species. Ecol. Evol. 3, $4872-4880$.

Jiménez Esquilín, A.E., Stromberger, M.E., Massman, W.J., Frank, J.M., Shepperd, W.D., 2007. Microbial community structure and activity in a Colorado Rocky Mountain forest soil scarred by slash pile burning. Soil Biom. Biochem. 39, 1111-1120.

Kalaji, H.M., Schansker, G., Ladle, R.J., Goltsev, V., Bosa, K., Allakhverdiev, S.I., Brestic, M., Bussotti, F., Calatayud, A., Dąbrowski, P., Elsheery, N.I., Ferroni, L., Guidi, L., Hogewoning, S.W., Jajoo, A., Misra, A.N., Nebauer, S.G., Pancaldi, S., Penella, C., Poli, D.B., Pollastrini, M., Romanowska-Duda, Z.B., Rutkowska, B., Serôdio, J., Suresh, K., Szulc, W., Tambussi, E., Yanniccari, M., Zivcak, M., 2014. Frequently asked questions about chlorophyll fluorescence: practical issues. Photosynth. Res. 122, 121-158.

Kalaji, H.M., Schansker, G., Brestic, M., Bussotti, F., Calatayud, A., Ferroni, L., Goltsev, V., Guidi, L., Jajoo, A., Li, P., Losciale, P., Mishra, V.K., Misra, A.N., Nebauer, S.G., Pancaldi, S., Penella, C., Pollastrini, M., Suresh, K., Tambussi, E., Yanniccari, M., Zivcak, M., Cetner, M.D., Samborska, I.A., Stirbet, A., Olsovska, K., Kunderlikova, K., Shelonzek, H., Rusinowski, S., Bąba, W., 2017. Frequently asked questions about chlorophyll fluorescence, the sequel. Photosynth. Res. 132, 13-66.

Kammann, C.I., Schmidt, H.P., Messerschmidt, N., Linsel, S., Steffens, D., Müller, C., Koyro, H.W., Conte, P., Joseph, S., 2015. Plant growth improvement mediated by nitrate capture in co-composted biochar. Sc. Rep. 5, 11080.

Karhu, K., Mattila, T., Bergström, I., Regina, T., 2011. Biochar addition to agricultural soil increased CH4 uptake and water holding capacity - Results from a short-term pilot field study. Agric. Ecosyst. Environ. 140, 309-313.

Kerré, B., Bravo, C.T., Leifeld, J., Cornelissen, G., Smolders, E., 2016. Historical soil amendment with charcoal increases sequestration of non-charcoal carbon: a comparison among methods of black carbon quantification. Eur. J. Soil Sci. 67 (3), 324-331.

Kopecký, M., Hédl, R., Szabó, P., 2013. Non-random extinctions dominate plant community changes in abandoned coppices. J. Appl. Ecol. 50, 79-87. http://dx.doi.org/ 10.1111/1365-2664.12010.

Korb, J.E., Johnson, N.C., Covington, W.W., 2004. Slash pile burning effects on soil biotic and chemical properties and plant establishment: recommendations for amelioration. Restor. Ecol. 12, 52-62.

Krause, S., Möseler, B.M., 1993. Vegetationskundliche und standortökologische Untersuchungen an einem ehemaligen Meilerplatz im Kermeter (Nordeifel), Decheniana 146, 91-95.

Lehmann, J., Joseph, S., 2009. Biochar for Environmental Management: Science and Technology. Ed Earthsc, London.

Lehmann, J., Gaunt, J., Rondon, M., 2006. Bio-char sequestration in terrestrial ecosystems - a review. Mitig. Adapt. Strat. GL. 11, 395-419.
Lloret, F., Vilà, M., 2003. Diversity patterns of plant functional types in relation to fire regime and previous land use in Mediterranean woodlands. J. Veg. Sci. 14, 387-398. http://dx.doi.org/10.1111/j.1654-1103.2003.tb02164.

Ludemann, T., 2011. Scanning the historical and scientific significance of charcoal production - local scale, high resolution kiln site anthracology at the landscape level. Sagvintvm Extra 11, 23-24.

Ludemann, T., 2010. Past fuel wood exploitation and natural forest vegetation in the Black Forest, the Vosges and neighbouring regions in western Central Europe. Palaeogeogr. Palaeoclimatol. Palaeoecol. 291, 154-165. http://dx.doi.org/10.1016/ j.palaeo.2009.09.013.

Ludemann, T., 2003. Large-scale reconstruction of ancient forest vegetation by anthracology-a contribution from the Black Forest. Phytocoenologia 33 (4), 645-666.

Mastrolonardo, G., Francioso, O., Certini, G., 2018. Relic charcoal hearth soils: a neglected carbon reservoir. Case study at Marsiliana forest, Central Italy. Geoderma 315, 88-95.

Mikan, C.J., Abrams, M.D., 1996. Mechanisms inhibiting the forest development of historic charcoal hearths in southeastern Pennsylvania. Can. J. For. Res. 26 (11), 1893-1898.

Mikan, C.J., Abrams, M.D., 1995. Altered forest composition and soil properties of historic charcoal hearts in southeastern Pennsylania. Can. J. For. Res. 25, 687-696. http://dx.doi.org/10.1007/s13398-014-0173-7.2.

Mikan, C.J., 1993. Edaphic Properties Relating to Altered Succession on Historic Charcoal Hearths in Pennsylvania. M.S. Thesis. Pennsylvania State University, State College.

Montanari, C., Prono, P., Scipioni, S., 2000. The study of charcoal-burning sites in the Appennine Mountains of Liguria (NW Italy) as a tool for forest history. In: Agnoletti, M., Anderson, S. (Eds.), Methods and Approaches in Forest History. Cabi Publishing, Oxon, UK, pp. 79-92.

Nelissen, V., Ruysschaert, G., Manka'Abusi, D., D’Hose, T., De Beuf, K., Al-Barri, B., Cornelis, W., Boeckx, P., 2015. Impact of a woody biochar on properties of a sandy loam soil and spring barley during a two-year field experiment. Eur. J. Agron. 62, 65-78.

Nelissen, V., Rütting, T., Huygens, D., Staelens, J., Ruysschaert, G., 2012. Maize biochars accelerate short-term soil nitrogen dynamics in a loamy sand soil. Soil Biol. Biochem. $55,20-27$.

Nocentini, S., Coll, L., 2013. Mediterranean forests. Human use and complex adaptive systems, in: Messier, C., Puetteman, K.J., Coates, D. (Eds.), Menaging Forests as Complex Adptive Systems - Building Resilience to the Challenge of Global Change. Oxon, pp. 214-243.

Oswald, B.P., Davenport, D., Neuenschwander, L.F., 1998. Effects of slash pile burning on the physical and chemical soil properties of Vassar soils. J. Sustain. Forest. 8 (1), 75-86.

Paillotin, G., 1976. Movement of excitations in the photosynthesis domain of photosystem II complex. J. Theor. Biology. 58, 237-252.

R core team, 2015. R: A language and Environment for statistical compunting. https:// www.R-project.org/.

Raab, T., Hirsch, F., Ouimet, W., Johnson, K.M., Dethier, D., Raab, A., 2017. Architecture of relict charcoal hearths in northwestern Connecticut, USA. Geoarchaeology 32 (4), $502-510$.

Raab, A., Takla, M., Raab, T., Nicolay, A., Schneider, A., Rösler, H., Bönisch, E., 2015. Preindustrial charcoal production in Lower Lusatia (Brandenburg, Germany): detection and evaluation of a large charcoal-burning field by combining archaeological studies, GIS-based analyses of shaded-relief maps and dendrochronological age determination. Quat. Int. 367, 111-122.

Reyes, O., Kaal, J., Arán, D., Gago, R., Bernal, J., García-Duro, J., Basanta, M., 2015. The effects of ash and black carbon (biochar) on germination of different tree species. Fire Ecol. 11, 119-133. http://dx.doi.org/10.4996/fireecology.1101119.

Rondon, M.A., Lehmann, J., Ramírez, J., Hurtado, M., 2007. Biological nitrogen fixation by common beans (Phaseolus vulgaris L.) increases with bio-char additions. Biol. Fertil. Soils 43, 699-708. http://dx.doi.org/10.1007/s00374-006-0152-z.

Silva, D.D., Kane, M.E., Beeson Jr, R.C., 2012. Changes in root and shoot growth and biomass partition resulting from different irrigation intervals for ligustrum japonicum thunb. Hort. Sci. 47, 1634-1640.

Thomas, S.C., Gale, N., 2015. Biochar and forest restoration: a review and meta-analysis of tree growth responses. New Forest. 46, 931-946. http://dx.doi.org/10.1007/ s11056-015-9491-7.

Sohi, S.P., Krull, E., Bol, R., 2010. A Review of Biochar and Its Use and Function in Soil, first ed., Adv. Agron. Elsevier Inc. 10.1016/S0065-2113(10)05002-9.

Strasser, R., Srivastava, A., Tsimilli-Michael, M., 2000. The fluorescence transient as a tool to characterize and screen photosynthetic samples. Probing Photosynth. Mech. Regul. Adapt. 445-483.

Strasser, R.J., Tsimilli-Michael, M., Srivastava, A., 2004. Analysis of the chlorophyll a fluorescence transient. Chlorophyll Fluoresc - Signat. Photosynth. 321-362. http:// dx.doi.org/10.1007/978-94-6091-478-2_12.

Vaccari, F.P., Baronti, S., Lugato, E., Genesio, L., Castaldi, S., Fornasier, F., Miglietta, F., 2011. Biochar as a strategy to sequester carbon and increase yield in durum wheat. Eur. J. Agron. 34, 231-238. http://dx.doi.org/10.1016/j.eja.2011.01.006.

Verheyen, K., Bossuyt, B., Hermy, M., Tack, G., 1999. The land use history (1278-1990) of a mixed hardwood forest in western Belgium and its relationship with chemical soil characteristics. J. Biogeogr. 26, 1115-1128. http://dx.doi.org/10.1046/j.13652699.1999.00340.x

Wittig, R., Walter, S., Xie, Y., 1999. Ehemalige Meilerplätze als Mikrostandorte des Galio odorati-Fagetum im Luzulo-Fagetum. Acta Biol. Benrodis 10, 57-68.

Yanai, Y., Toyota, K., Okazaki, M., 2007. Effects of charcoal addition on N2O emissions from soil resulting from rewetting air-dried soil in short-term laboratory experiments. J. Soil Sci. Plant Nutr. 53, 181-188.

Young, M.J., Johnson, J.E., Abrams, M.D., 1996. Vegetative and edaphic characteristics on relic charcoal hearths in the Appalachian mountains. Vegetatio 125, 43-50. http://dx.doi.org/10.1007/BF00045203.

Yu, O.Y., Raichle, B., Sink, S., 2013. Impact of biochar on the water holding capacity of loamy sand soil. Int. J. Energy Environ. Eng. 4, 44. 